\title{
New Oligocene to Early Miocene Palynomorph Zonation of GZ-1 Well, Onshore Western Niger Delta, Nigeria
}

\author{
*AMIEWALAN, FO; BALOGUN, FO \\ Department of Geology, University of Benin, Benin city, Nigeria \\ Department of Geology, Federal University of Lafia, Nasarawa State, Nigeria. \\ *Corresponding Author Email: amiewalanflorence@gmail.com,fo.balogun@science.fulafia.edu.ng
}

\begin{abstract}
Palynological studies was carried out on GZ-1 well from the onshore western Niger Delta in order to recognized a new detected developments in the varieties of key pollen and spore taxa that have shorter and more distinguished interval zones to advance stratigraphical delineation. Palynological analysis was carried out using the conventional maceration technique for recovering acid insoluble organic-walled microfossils from sediments. The result yielded rich and diversified palynomorphs. The main assemblage were dominated by angiosperm pollen grain (dominant global flora from Late Cretaceous onwards) followed by pteridophytes/bryophyte spore. Dinoflagellate cysts, on the contrast, were less diverse while the Gymnosperm pollen were scarce. The identified palynomorph were used to establish seven main zones - AF1 Psilatricolporites crassus zone, AF2 Verrucatosporites usmensis zone, AF3 Triplochiton scleroxylon zone, AF4 Crassoretitriletes vanraadshooveni zone, AF5 Acrostichum aureum zone, AF6 Gemmatriporites ogwashiensis zone and AF7 Retitricolporites irregularis zone in this study. Established on quantitative events, the zones were also divided into seven subzones with some having finer subdivisions into (a) and (b) ranging in age from Early Oligocene to Early Miocene. Previous unfiled event trends of important indicator taxa of spores and pollen accredited to Pelliceria, Caesalapinoideae, Stenochlaena palustris, Polypodiaceae, Lygodium microphyllum, Polypodiaceae, Adiantaceae and Amanoa (Euphorbiaceae) have assisted improvement of formerly used palynological zonation schemes in the Niger Delta. It is anticipated that this quantitative zonation scheme erected, will help with imminent palynostratigraphical studies in the onshore Niger delta area.
\end{abstract}

DOI: https://dx.doi.org/10.4314/jasem.v25i4.4

Copyright: Copyright (C) 2021 Amiewalan and Balogun. This is an open access article distributed under the Creative Commons Attribution License (CCL), which permits unrestricted use, distribution, and reproduction in any medium, provided the original work is properly cited.

Dates: Received: 12 December 2020; Revised: 26 January 2021; Accepted: 12 February 2021

Keywords: Pollen and spores, Oligocene, Miocene, palynological zonation, Niger Delta.

The Cenozoic Niger Delta Basin is one of the Southern Nigeria sedimentary basins. Geographically, as indicated by Reijers et al., (1997), it is situated between Latitudes $3^{\circ}$ and $6^{\circ} \mathrm{N}$ and Longitudes $5^{\circ}$ and $8^{\circ} \mathrm{E}$. Many researchers had worked on the provincial significance of palynological relationship in the region. Germeraad et al., (1968), carried out the most comprehensive palynological research to date on some of the Tertiary sediment from the world's tropical areas - South America, Asia and West Africa. They heartened the improvement of palynological research in Venezuela and later in the Niger Delta. Consequently, Evamy et al., (1978), adopted a formal palynological zonation scheme for the Niger delta using alpha numeric nomenclature - P200, P300, P400, P500, P600, P700, P800 and P900 zones and subzones. However, facts about the individual marker pollen types are not made to the public and remains in the developed company for proprietary reasons. Legoux (1978), also established independent, but then a corresponding palynological zonation schemes. He employed specific marker taxa and their relative abundances, with the description of numerous new pollen types. Similarly, Poumot (1989), utilized palynoecological groups to infer 'palynocycles' and 'mega-palynocycles' for Late Miocene to Pliocene sections of the Niger Delta. The study is valuable primarily for understanding of depositional environments, changes in succession and the presence of sequence, but has insignificant utilization for age dating and stratigraphical correlation. Morley (1996a, 1996b), was the first to recommend sequence stratigraphical observations based on palynology, vegetation and climate, which was later advanced by Adebayo and Ojo (2014). Among the palynological zonation schemes for the Niger Delta, the schemes of Germeraad et al., (1968); Evamy et al., (1978) and Legoux (1978) are centered largely on qualitative occurrences, while the schemes of Morley (2000), take account of palaeoclimatic controls and are quantitatively useful in diverse parts and age intervals in the Niger Delta. The scheme of Evamy et al., (1978) can be useful transversely in the whole of Niger Delta region, even though the zones and sub-zones are too 
large to capture understated palynological events. The zonation of Morley (2000), offers additional improvements, with quantitative events, but then is less consistent in the western part of the Niger Delta. Adeonipekun et al., (2015), worked on Late Miocene to Early Pleistocene three exploration wells from the western delta region of the Niger Delta to find an acceptable solution that will aid the recognition of shorter interval zones, understated subtle events and advance the palynostratigraphical resolution of the region. They discovered new palynological features that assisted them to defined five main palynological assemblage zones from their study. New events and features were recognized and the varieties and occurrence developments of the palynomorphs used have been verified in over 100 exploration wells from across the offshore Niger Delta. With these, missing sections were identified and enhanced stratigraphical modelling through the use of sequence stratigraphical procedures. /This study is on new palynomorphs zonation in the Early Oligocene to Early Miocene sediments of GZ-1 well, onshore western Niger Delta. Fig. 1 shows the location of GZ-1 well.

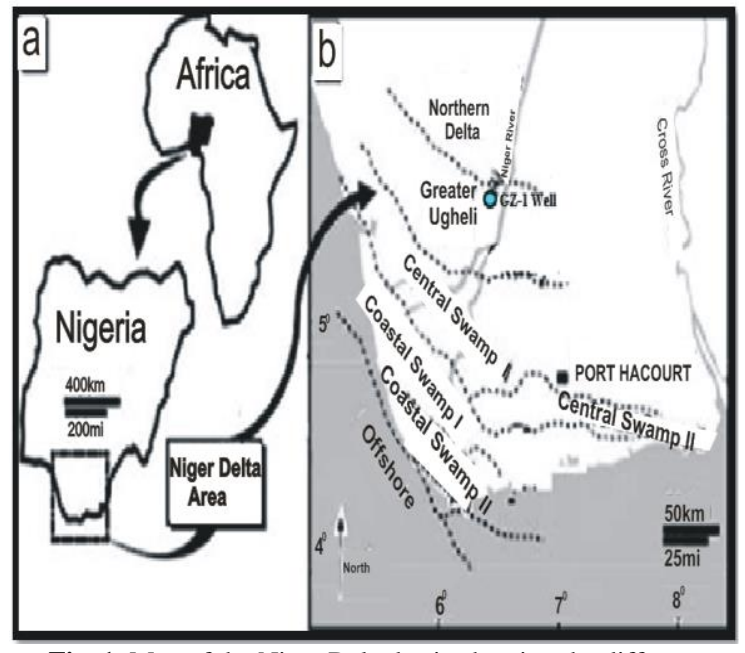

Fig. 1: Map of the Niger Delta basin showing the different depositional belts (depobelts). (After Doust and Omatsola 1990). The dot indicates the location of the study well.

Geological setting: The geology of the Niger delta has been described and defined by Short and Stauble (1967). Reijers (2011), submitted that the formation of the Niger Delta began in the Eocene, with the first deltaic sediments deposited to the south and east of the former Cretaceous coastline in the 'northern delta depo-belt'. Several transgressive and regressive events have successively taken place (Short and Stauble 1967; Evamy et al., 1978) and according to Reijers (2011), these processes have given rise to the delta complex being deposited farther and farther offshore to the south. The lithofacies of the Cenozoic Niger
Delta is mainly assembled into continental, transitional and marine leading to three Formations, viz., in ascending order: the Akata, Agbada and the Benin Formations. Fig. 2. The Akata Formation (marine sediments) is from Paleocene to Recent. Short and Stauble (1967); Reijers et al., (1997); Doust and Omatsola (1990). The Imo shale is the outcrop equivalent categorized by continuous, uniform shale and turbidites sand deposition in marine environment. The shales of this Formation are largely under compacted. Akpoyovbike (1978). On top of the marine sequence is the Eocene to Recent Agbada Formation. Avbovbo (1978). The Agbada Formation consists of repeated coarsening-upward regressive sequences composed of shales, siltstones, and sandstones deposited in dalta front and lower delta plain settings. Weber (1971). It's establishes the actual deltaic portion of the sequence. Lambert-Aikhionbare and Ibe (1984), opined that the Agbada Formation is composed of the petroleum bearing reservoir rocks while the Akata Formation bears the source rocks. Ekweozor and Okoye (1980). Topping the sequence is generally the continental Benin Formation, which consist of a succession of Eocene to Holocene massive poorly indurated sandstones, thin shales, coals, and gravels of continental to upper delta plain origin. Okosun et al., (2016). The Benin Formation is superimposed by diverse types of Quaternary deposits, Boboye and Fawora (2007), deposited on littoral and deltaic plain environments. Weber and Daukoru (1975). Fig. 2 shows the schematic representation of diachronous nature of major lithofacies units and stratigraphic relationships of clay-filled channels on the Delta Flanks.

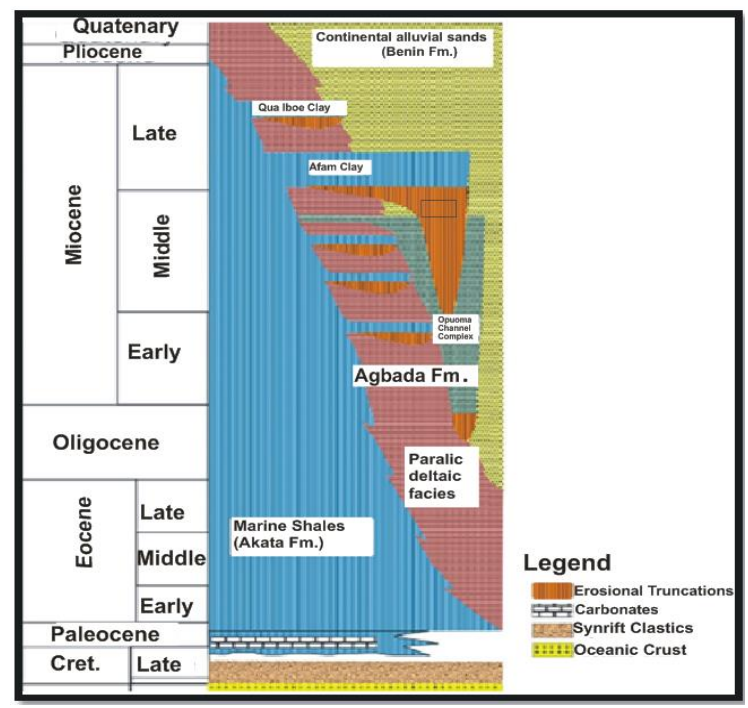

Fig 2: Schematic Representation of Diachronous Nature of Major Lithofacies Units and Stratigraphic Relationships of Clay-filled Channels on the Delta Flanks (Modified after Doust and Omatsola, 1990 and Lawrence et al., 2002). 


\section{MATERIALS AND METHODS}

Twenty grams from each of the ditch cutting samples provided by NPDC were used for the palynological study, following the technique of Wood et al., (1996). The sediment were digested for 30 minutes in $40 \%$ hydrochloric acid to remove carbonates, then 72 hours in $48 \%$ hydrofluoric acid for the removal of silicates. This was followed by complete neutralization with distilled water. Removal of the fluoride gel (formed during the $\mathrm{HF}$ treatment) was done using hot concentrated $\mathrm{HCl}$ acid and wet sieving the residue using a $10-\mu \mathrm{m}$ polypropylene Estal Mono sieve. The residues were oxidized for 30 minutes in $70 \% \mathrm{HNO}_{3}$ to render the fossils translucent for transmitted light microscopy; rinsed in $2 \% \mathrm{~K} \mathrm{OH}$ solution to neutralize the acid, swirled and stained with Safranin-O to increase the contrast for identification and photography. Heavy-liquid separation with $\mathrm{ZnBr}_{2}$ (2.2 s.g) and separating of the remains with a $20 \mu \mathrm{m}$ sieve. The residues were spotted with pipette on cover slip, left to dry and were then mounted on glass slides using Canada basalm as adhesive mounting medium. Palynomorph residue were then studied with a transmitted light binocular microscope to identify the different palynomorphs (pollen, spores and dinoflagellate cysts). Where possible, about 200 - 300 grains including (fern spores and pollen) were counted from each slide for quantitative palynological analysis. Photomicrographs of well-preserved palynomorphs were taken with the aid of Sony digital camera (14.1 mega pixels). Identification of Palynomorphs (pollen, spores and dinoflagellate cysts) was undertaken by matching with palynological work of relevant publications and web-based albums. The statistical data (palynological count) obtained was computerized using the StrataBug 2.0 software with depth on the yaxis and the identified taxa on the x-axis. The works of Germeraad et al., (1968), Evamy et al., (1978) and
Legoux (1978) were primarily used for the palynological zonation. Consequently, a new zonation scheme identified in this study was established and defined in this paper. Importance was placed on the First Downhole Occurrence (FDO)/Last Appearance Datum (LAP) than on the First Appearance Datum (FAP)/Last Downhole Occurrence (LDO) of chronostratigraphically significant taxa when defining palynozones to prevent the caving of microfossils associated with ditch cutting samples. Seven main zones and subzones were demarcated and two of the subzones were further subdivided into two each. Qualitative and quantitative events of both the single taxa and the whole assemblage composition establishes the sub-zones. Thus, they are subject to biological evolution/extinction in addition to palaeoclimatic and ecological factors.

\section{RESULTS AND DISCUSSION}

Palynostratigraphy in GZ-1 well: The palynological analysis yielded rich and diversified palynomorphs of seventy one genera and one hundred and one (101) species. Seventy-four (74) pollen species, fourteen (14) spore species and thirteen (13) dinoflagellate cysts species - six (6) Peridinoid cysts with seven (7) Gonyaulacoid cysts were recovered. The main assemblage were dominated by angiosperm pollen grain (dominant global flora from Late Cretaceous onwards) followed by pteridophytes/bryophyte spore. Dinoflagellate cysts, on the contrast, were less diverse while the Gymnosperm pollen were scarce. In the palynomorph proportion, miospore make up about $86.7 \%$. The Angiosperm pollen (70 \%), Gymnosperm pollen $(2.9 \%)$, monolete spore $(4.9 \%)$, trilete spore $(8.9 \%)$ whereas marine origin (dinoflagellates cysts) make up $12.8 \%$. The Gonyaulacoid $(6.9 \%)$ are more dominant than Peridinoid $(5.9 \%)$ in the recovered dinoflagellate cysts. Table 1.

\begin{tabular}{|c|c|c|c|c|c|c|c|}
\hline $\begin{array}{c}\text { Types of } \\
\text { palynomorph }\end{array}$ & $\begin{array}{l}\text { Monolete } \\
\text { spore }\end{array}$ & $\begin{array}{l}\text { Trilete } \\
\text { spore }\end{array}$ & $\begin{array}{l}\text { Angiosperm } \\
\text { pollen }\end{array}$ & $\begin{array}{l}\text { Gymnosperm } \\
\text { pollen }\end{array}$ & $\begin{array}{l}\text { Gonyaulacoid } \\
\text { dinocysts }\end{array}$ & $\begin{array}{l}\text { Peridinoid } \\
\text { dinocysts }\end{array}$ & Total \\
\hline $\begin{array}{l}\text { species and } \\
\text { their count }\end{array}$ & 5 & 9 & 71 & 3 & 7 & 6 & 101 \\
\hline $\begin{array}{l}\text { Approx. } \\
\text { Percentage } \\
\text { value }\end{array}$ & 5 & 9 & 70 & 3 & 7 & 6 & 100 \\
\hline
\end{tabular}

The proportion of angiosperm pollen recovered are the highest in the studied well as shown in table 1. Fig. 3 shows the area plot of the percentage value of the different palynomorphs. The following species characterized the monolete spores: Verrucatosporites spp., Verrucatosporites usmensis and Varirugosporites spp. while the trilete spore were characterized by - Acrostichum aureum, Cyathidites australis, Leiotriletes spp., Magnastriatites howardi, Polypodiaceoisporites spp., Elaeis guineensis and Foveotriletes margaritae among others. The gymnosperm pollen are exemplified herein by two genera - Ephedripites and Podocarpidites. They were sparsely represented in the well. The following species: Lingulodinium spp., Selenopemphix spp., Pheiodinium africanus, Lejeunecysta spp., 
Cordosphaeridium inodes, Operculodinium spp. among others represents the dinoflagellate cysts. The commonest species are the Lejeunecysta spp. Also, foraminiferal test linings, freshwater algae and fungal spores were recognized.

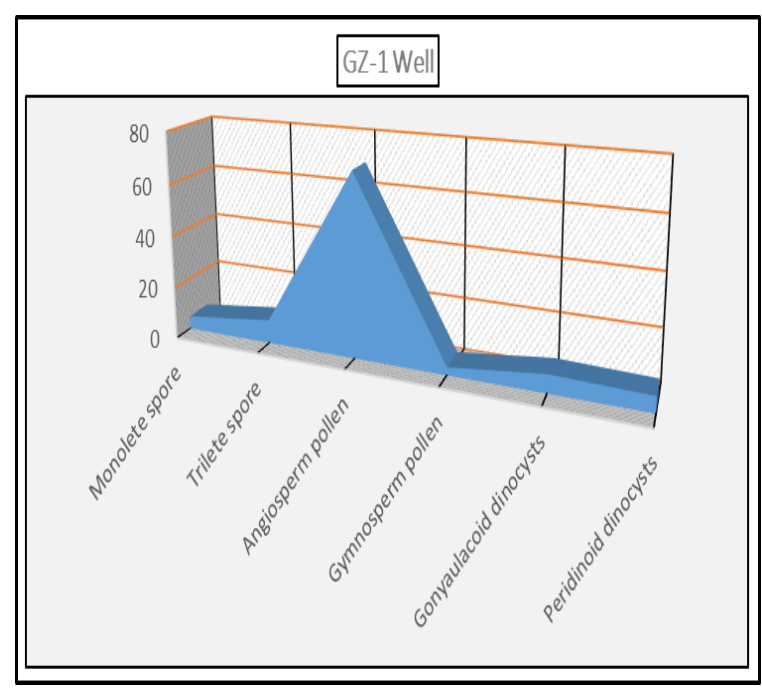

Fig. 3: Shows the area plot of the percentage value of the different palynomorphs in GZ-1 well.

Descriptions and characteristics of new zones and sub-zones in the study well: The corresponding zones compares with the zones of Germeraad et al., (1968); Evamy et al., (1978) and Legoux (1978). Table 2 shows the abbreviations and definitions used in the zonation discussion.

Palynological zones demarcated in the studied well: Seven main zones have been documented, AF1 (Psilatricolporites crassus zone), AF2 (Verrucatosporites usmensis zone), AF3 (Triplochiton scleroxylon zone), AF4 (Crassoretitriletes vanraadshooveni zone), AF5 (Acrostichum aureum zone), AF6 (Gemmatriporites ogwashiensis zone) and AF7 (Retitricolporites irregularis zone). Also seven subzones were demarcated - AO1, AO2, AO3, AO4, AO5, AO6 and AO7.
Two of the subzones (AO2 and AO3) were further subdivided into ( $\mathrm{a}$ and $\mathrm{b}$ ). Within the Early Oligocene two sub-zones (AO1 and AO2) were established. One subzone each (AO3 and AO4) was demarcated within Early - Late Oligocene and Late Oligocene - Early Miocene.

Three subzones (AO5, AO6 and AO7) were defined within the Early Miocene. The assemblages of the new zones and sub-zones have more comprehensive explanations of their distributions and relative abundances of the component taxa present within them.

Table 4 reveals the new palynostratigraphical biozonation of the Early Oligocene - Early Miocene erected for GZ-1 well, based on pollen, spore, dinoflagellate cysts distributions and quantitative events.

ZONE AF1: (Psilatricolporites crassus zone) - Early Oligocene

Top of zone: QB Striatricolpites catatumbus

Base of zone: Not seen in the studied intervals.

Characteristics: General low/high frequencies number of palynomorph. Rare or absent of palynomorph at some depths. QT Psilatricolporites crassus. PO Verrucatosporites spp. and Cicatricosisporites dorogensis. DD Pachydermites diederixi. Complete absent of Zonocostites ramonae. QB Laevigatosporites cf. discordatus, Retitricolporites irregularis, Praedopollis flexibilis, Racemonocolpites hians, Retibrevitricolporites obodoensis, Retitricolporites irregularis and Acrostichum aureum. Rare Ctenolophonidites costata. RO Protoperidiniaceae. Presence of reworked palynomorph (Psilatricolporites operculatus, Mauritiidites crassiexinus and Proxapertites cursus). Equivalent zones: ?P520 -P540.

Table 2: Abbreviations used in the palynological zonation scheme for this study.

\begin{tabular}{ll}
\hline Abbreviation & Definition \\
\hline FDO & First Downhole Occurrence (stratigraphic top or extinction event) \\
LDO & Last Downhole Occurrence (stratigraphic base or evolutionary appearance) \\
LAD & Last Appearance Datum \\
FAD & First Appearance Datum \\
OB & Quantitative base (a decrease in numerical abundance down-section) \\
QT & Quantitative top (an increase in numerical abundance down- section) \\
DD & Downhole decrease \\
PO & Peak occurrence \\
RO & Regular occurrence \\
DI & Downhole increase \\
TRO & Top Regular Occurrence \\
Spp. & Specie \\
Cf. & Compared with \\
\hline
\end{tabular}


Aff. Affinity

Table 3: Some of the recovered pollen and spore with their author references, botanical affinities and ecologies for the studied well.

Taxon, author

Acrostichum aureum, Kar (1992)

Cicatricosisporites dorogensis, Potonié and

Gelletich (1933)

Crassoretitriletes vanraadshooveni, Germeraad et al., (1968)

Elaies guineensis

Laevigatosporites haardti, Thomson and Pflug (1953)

Magnastriatites howardi, Germeraad et al., (1968)

Verrucatosporites usmensis, Van Der Hammen (1956b)

Ephedripites spp. Jardine and Magloire (1965)

Podocarpus milanjianus, William et al., (2013)

Arecipites exilimuratus, Legoux (1978)

Belskipollis elegans, Legoux (1978)

Echiperiporites estelae, Germeraad et al., (1968)

Graminidites annulatus, Germeraad et al., (1968)

Pachydermites diederixi, Salard- Cheboldaeff (1990)

Peregrinipollis nigericus, Clarke (1966)

Praedapollis flexibilis, Legoux (1978)

Praedapollis africanus, Boltenhagen and Salard-

Cheboldaeff (1973)

Psilatricolporites crassus, Van der Hammen and

Wymstra (1964)

Psilatricolporites operculatus, Van Der Hammen and Wymstra (1964)

Racemonocolpites hians, Legoux (1978)

Retibrevitricolporites obodoensis, Legoux (1978)

Retibrevitricolporites protrudens, Legoux (1978)

Retitrescolpites typicus, Sah (1967)

Retitricolporites irregularis, Van der Hammen and Wymstra (1964)

Spirosyncolpites brunii, Legoux (1978)

Verrutricolporites rotundiporis, Van Der

Hammen and Wymstra (1964)

Zonocostites ramonae Germeraad, et al., (1968)

\section{Botanical Affinity \\ Natural Habitat/Ecology}

Polypodiaceae, Adiantaceae

Mangrove swamp

Schizaeaceae, Lygodiaceae, Mesophilous forest/Montane

Dicksoniaceae

Forest

Lygodium microphyllum

Humid marsh and coastal swamps

Palmae

Rain forest

Polypodiacece

Mangrove swamp

Parkeriaceae,Ceratopteris,

Adiantaceae,

A tropical freshwater-fern

Stenochlaena

Polypodiaceae

palustris, Mesophilous forest/Lowland

Ephedraceae

Podocarpaceae

Arecaceae

Acanthaceae

Malvaceae, Thespesia populnea

Poaceae (Gramineae)

Clusiaceae, Hyperiacaceae

Caesalapinoideae

Fabaceae/Leguminosae?

Rainforest

Savanna

Afromontane

Rain forest

Montane Forest

Coastal swamp

Savanna

Coastal swamp/Fresh Water

Swamp

Riverine/Leguminous plants

Rain forest

Fabaceae/Leguminosae?

Rain forest

Pelliceria, Caesalapinoideae

Mangrove swamp

Euphorbiaceae, Alchornea cordifolia

Palmae

Riverine/Freshwater swamp

Euphorbiaceae/Rubiaceae

Freshwater Swamp

Freshwater swamp/Lowland Rain

forest

Euphorbiaceae/Rubiaceae

Freshwater swamp

Oleaceae

Sub-tropical broad leaved ever green tree

Amanoa (Euphorbiaceae)

Freshwater swamp/Riverine

Loganiaceae, Fagraea sasakii

Rain forest

Crenea, Lythraceae

Mangrove/Coastal swamp

Rhizophoraceae, Bruguiera, Ceriops and Caralia

Mangrove swamp
ZONE AF2: (Verrucatosporites usmensis zone) Early Oligocene

Top of zone: QT Retitricolporites irregularis

Base of zone: QB Striatricolpites catatumbus

Characteristics: Several barren depth were identified within the zone. QB Verrucatosporites usmensis, LDO Bombacacidites annae and Magnastriatites howardi. Consistent Retibrevitricolporites protrudens, DD Podocarpus milanjianus. Rare Graminidites annulatus. RO freshwater swamp species and marine palynomorph - Polysphaeridium zoharyi and Lejeunecysta spp., low in abundance of mangrove swamp. Cordosphaeridium inodes specie is restricted to this zone of the well. Presence of reworked pollen and spore (Mauritiidites crassiexinus, Verrucatosporites usmensis and Psilatricolporites operculatus).
Equivalent zone: P560

Sub-zone AO2a: (Early Oligocene)

Top of sub-zone: QB Verrustephanocolporites complanatus

Base of sub-zone: QB Striatricolpites catatumbus

Characteristics: Consistent Zonocostites ramonae, Pachydermites diederixi, Praedopollis flexibilis, Racemonocolpites hians, Retitricolporites irregularis, Striatricolpites catatumbus, Peregrinipollis nigericus, Verrucatosporites usmensis toward the base of the subzone. PO Proteacidites cooksonii. LDO Bombacacidites annae and Magnastriatites howardi. Equivalent zone: P560 (upper part). 
New Oligocene to Early Miocene Palynomorph Zonation of GZ-1 Well.....

Table 4: New palynostratigraphical biozonation of the Early Oligocene - Late Miocene erected for GZ-1 well, Onshore Niger Delta, based on pollen, spore, dinoflagellate cysts distributions and quantitative events. The zones are comparable with zonation scheme of Evamy et al., (1978); Germeraad et al., (1968) and Legoux (1978).

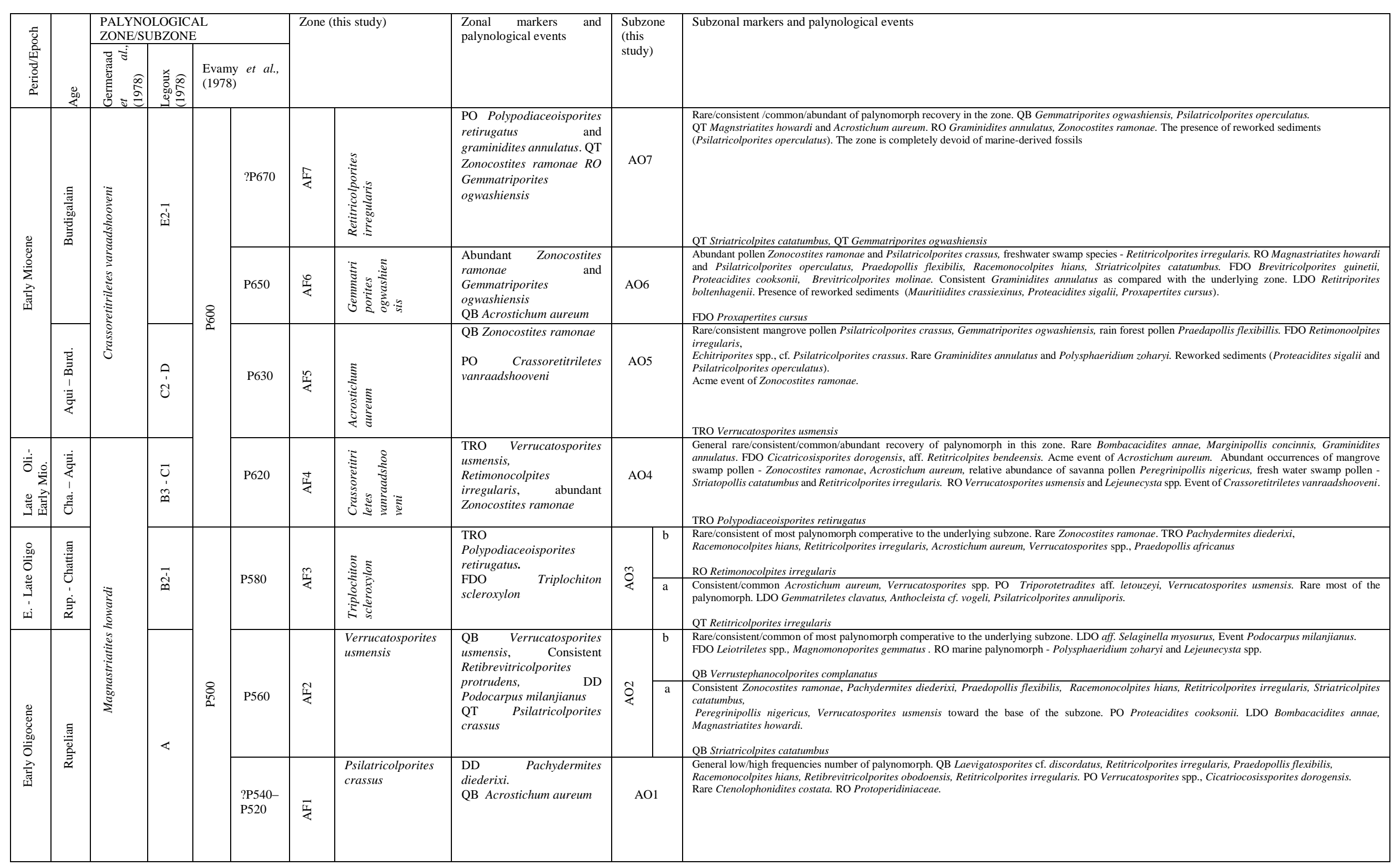


Sub-zone AO2b: (Early Oligocene)

Top of sub-zone: QT Retitricolporites irregularis

Base of sub-zone: QB Verrustephanocolporites complanatus

Characteristics: Rare/consistent/common of most palynomorph comparative to the underlying subzone. LDO aff. Selaginella myosurus, Event of Podocarpus milanjianus. FDO Leiotriletes spp. and Magnomonoporites gemmatus. RO marine palynomorph - Polysphaeridium zoharyi and Lejeunecysta spp.

Equivalent zone: P560 (lower part).

ZONE AF3: (Triplochiton scleroxylon zone) Early Late Oligocene

Top of zone: TRO Polypodiaceoisporites retirugatus Base of zone: QT Retitricolporites irregularis

Characteristics: Common freshwater swamp and lowland rainforest species. Rare Graminidites annulatus. Presence of reworked pollen and spore (Psilatricolporites operculatus, Proteacidites sigalii and Verrucatosporites usmensis). PO Triporotetradites aff. Letouzeyi. Abundant mangrove swamp pollen. FDO Triplochiton scleroxylon. QT Polysphaeridium zoharyi and QB Lejeunecysta spp. $\mathrm{RO}$ aff. Retitricolpites bendeensis.

Equivalent zone: P580.

Sub-zone AO3a: (Early - Late Oligocene)

Top of sub-zone: RO Retimonocolpites irregularis Base of sub-zone: QT Retitricolporites irregularis Characteristics: Consistent/common Acrostichum aureum, Verrucatosporites spp. PO Triporotetradites aff. letouzeyi, Verrucatosporites usmensis. Rare most of the palynomorph. LDO Gemmatriletes clavatus, Anthocleista cf. vogeli, Psilatricolporites annuliporis. Equivalent zone: P580 (lower part).

Sub-zone AO3b: (Early - Late Oligocene). Top of sub-zone: TRO Polypodiaceoisporites retirugatus

Base of sub-zone: RO Retimonocolpites irregularis Characteristics: Rare/consistent of most palynomorph comparative to the underlying subzone. Rare Zonocostites ramonae. TRO Pachydermites diederixi, Racemonocolpites hians, Retitricolporites irregularis, Acrostichum aureum, Verrucatosporites spp. and Praedopollis africanus.

Equivalent zone: P580 (upper part).

ZONE AF4: (Crassoretitriletes vanraadshooveni zone) Late Oligocene - Early Miocene

Top of zone: TRO Verrucatosporites usmensis

Base of zone: TRO Polypodiaceoisporites retirugatus

Characteristics:

General

rare/consistent/common/abundant recovery of palynomorph in the zone. Rare Bombacacidites annae, Marginipollis concinnis, Graminidites annulatus. FDO Cicatricosisporites dorogensis, aff. Retitricolpites bendeensis. Acme event of Acrostichum aureum. Abundant occurrences of mangrove swamp pollen - Zonocostites ramonae, Acrostichum aureum, relative abundance of savanna pollen Peregrinipollis nigericus, fresh water swamp pollen - Striatopollis catatumbus and Retitricolporites irregularis. TRO Verrucatosporites usmensis and Retimonocolpites irregularis. RO Lejeunecysta spp. Event of Crassoretitriletes vanraadshooveni restricted to this zone of the well. The presence of reworked sediments (Ephedripites spp., Verrucatosporites usmensis, Psilatricolporites operculatus).

Equivalent zone: P620

ZONE AF5: (Acrostichum aureum zone) - Early Miocene

Top of zone: FDO Proxapertites cursus

Base of zone: TRO Verrucatosporites usmensis

Characteristics: Rare/consistent mangrove pollen

Psilatricolporites crassus, Gemmatriporites ogwashiensis, rain forest pollen - Praedopollis flexibilis. FDO Retimonocolpites irregularis, Echitriporites spp., cf. Psilatricolporites crassus. Rare Graminidites annulatus and Polysphaeridium zoharyi. The presence of reworked sediments (Proteacidites sigalii and Psilatricolporites operculatus). Acme event of Zonocostites ramonae.

Equivalent zone: P630

ZONE AF6: (Gemmatriporites ogwashiensis zone) Early Miocene

Top of zone: QT Striatricolpites catatumbus, QT Gemmatriporites ogwashiensis

Base of zone: FDO Proxapertites cursus

Characteristics: Abundant occurrences of mangrove swamp vegetation pollen - Zonocostites ramonae and Psilatricolporites crassus, freshwater swamp species Retitricolporites irregularis. Abundant Gemmatriporites ogwashiensis. RO Magnastriatites howardi and Psilatricolporites operculatus, Praedopollis flexibilis, Racemonocolpites hians, Striatricolpites catatumbus. FDO Brevitricolporites guinetii, Proteacidites cooksonii, Brevitricolporites molinae. Consistent Graminidites annulatus as compared with the underlying zone. LDO Retitriporites boltenhagenii. Presence of reworked sediments (Mauritiidites crassiexinus, Proteacidites sigalii, Proxapertites cursus).

Equivalent zone: P650

ZONE AF7: (Retitricolporites irregularis zone) Early Miocene

Top of zone: Not seen in studied sections. 
Base of zone: QT Striatricolpites catatumbus, QT Gemmatriporites ogwashiensis

Characteristics: Rare/consistent/common/abundant of palynomorph recovery in the zone. QB Gemmatriporites ogwashiensis, Psilatricolporites operculatus. QT Magnastriatites howardi and Acrostichum aureum. RO Graminidites annulatus and Zonocostites ramonae. PO Polypodiaceoisporites retirugatus. The presence of reworked sediments (Psilatricolporites operculatus). The zone is completely devoid of marine-derived fossils.

Equivalent zone: ?P670

Dating of the zonation scheme: The ages assigned to the zones and sub-zones are shown in table 4, that demonstrates relationships to the previous schemes of Germeraad et al., (1968), Evamy et al., (1978) and Legoux (1978).

Early Oligocene: The upper part of the Early Oligocene age (P560) was delineated in GZ-1 well at $9447 \mathrm{ft}$. based on the increase of Retibrevitricolporites obodoensis/protrudens. Oboh et al., (1997), used the presence of the specie Retibrevitricolporites obodoensis to define the Oligocene age. The specie Loranthacites natalie recovered in Oligocene sediment likewise agrees with the work of SalardChebodaeff (1990), who age dated the Oligocene to Eocene strata in Cameroun, Gabon and Congo using Loranthacites natalie specie. P540 was not delineated in the well due to the absence of Arecipites exilimuratus. The lower part of the Early Oligocene (P520) was demarcated at 10,172 ft. established based on the occurrence of Racemonocolpites hians. The marine dinoflagellate cysts encountered in the studied well generally come to an agreement with the sporomorph date mentioned above. Durugbo (2013), recorded Lejeunecysta and Selenopemphix spp. as developed during the Palaeocene and had their peak all through the Oligocene in the Niger Delta, Nigeria. Similarly, Bruno et al., (2011), identified abundant and fairly well-preserved dinoflagellate cysts which enabled the recognition of Oligocene age using largely Lejeunecysta species signified by cf. Lejeunecysta communis, Lejeunecysta lata, Lejeunecysta spp. cf. Lejeunecysta granosa, cf. Lejeunecysta globosa, Lejeunecysta beninensis and additional dinoflagellate cysts such as Pheiodinium magnificum, Pheiodinium africanum, Tuberculodinium vancampoae, Selenopemphix nephroides and Cordosphaeridium inodes. The Oligocene age was delineated by Biffi and Grignani (1983), based on Pheiodinium magnificum, Pheiodinium africanum with various species of Lejeunecysta and Selenopemphix recovered from the Niger Delta sediments. Pheiodinium africanum was used in association with species of Lejeunecysta represented by Lejeunecysta spp. cf. L granosa, Selenopemphix nephroides and Cordosphaeridium inodes to support the sporomorphs marker species to establish the Oligocene age in the studied well.

Late Oligocene: The quantity base of Peregrinipollis nigericus define the base of the latest Oligocene age in the well. This is similar to the palynological zonal scheme (P580) of Evamy et al., (1978) of the Niger Delta Basin, Magnastriatites howardi zone of Germeraad et al., (1968) and latest Oligocene (Chattian) spores and pollens B2-1 zone of Legoux (1978). The late Oligocene age was demarcated at $6725 \mathrm{ft}$. based on the quantity base of Peregrinipollis nigericus. Essien et al., (2016), Adeigbe and Ochigbo (2017), used similar palynomorph to age date Middle Miocene to Early Oligocene sediment. The late Oligocene interval is also categorized by significant reduction in percentage of occurrences of Zonocostites ramonae as recorded in the well.

Oligocene/Miocene Boundary: The First Downhole Occurrence (FDO) of Cicatricosisporites dorogensis is generally used as an Oligocene/Miocene boundary marker specie in Nigeria. Germeraad et al., (1968), Legoux (1978), had assigned the age range of the Agbada Formation between Oligocene and Early Miocene using the same marker specie. Essien et al., (2016) and Artzner and Dorhofer (1978), delineated the Oligocene/Miocene boundary $(\mathrm{O} / \mathrm{M})$ boundary by the FDO of Cicatricosisporites dorogensis and the Last Downhole occurrence (LDO) of Verrutricolporites laevigatus. The FDO occurrence of Cicatricosisporites dorogensis identified at $5688 \mathrm{ft}$. was used to define Oligocene/Miocene boundary in the well.

Early Miocene: Early Miocene age (P620) was delineated in the present study based on the First Downhole Occurrence of Praedapollis africanus at $4962 \mathrm{ft}$. This agrees with the work of Legoux (1978), who used the marker specie to establish the early phase of Miocene and is also comparable to the submission of Evamy et al., (1978) (P620) for the Niger Delta, Nigeria. Aquitanian to Burdigalian (P630) age was delineated at $4039 \mathrm{ft}$. based on the increase of Praedapollis flexibillis. Burdigalian (P650) age was delineated at $3186 \mathrm{ft}$. based on the quantity base of Magnastriatites howardi marker specie. Adeigbe and Ochigbo (2017), had delineated age range from Middle Miocene to Early Oligocene using Magnastriatites howardi, Praedapollis flexibillis, Praedapollis africanus, Cicatricosisporites dorogensis, Peregrinipollis nigericus, Retibrevitricolporites obodoensis/protrudens, Arecipites exilimuratus and Racemonocolpites hians species. Oloto (2014), 
likewise used the occurrence of Verrutricolporites rotundiporis and Praedapollis africanus occurrence to support the existence of P620-P770 subzone (EarlyMiddle Miocene). According to Germeraad et al., (1968), Rhizophora (Zonocostites ramonae) is absent from pre-Miocene sediments and start occurring abruptly in high percentages in the lowermost Miocene. From the record of this pollen in the well, it agrees with the report of Germeraad et al., (1968).

Seven main zones have been documented, AF1, AF2, AF3, AF4, AF5, AF6 and AF7 in this study. Boundaries of the AF zones corresponds with the P500 and P600 zone and sub-zones P520, ?P540, P560, P580, P620, P630. P650 and ?P670 of Evamy et al., (1978) with more inclusive descriptions of the distributions and relative quantities of the constituent taxa obtained. The supreme important indicator taxa (zonal markers) are Psilatricolporites crassus, Verrucatosporites usmensis, Triplochiton scleroxylon, Crassoretitriletes vanraadshooveni, Acrostichum aureum, Gemmatriporites ogwashiensis and Retitricolporites irregularis. Zones AF1, AF2 and AF3 (P520 - ?P540, P560 and P580) were characterized by sporomorph marker species (Racemonocolpites hians, Retibrevitricolporites obodoensis and Peregrinipollis nigericus) in association with marine species of Pheiodinium africanum Lejeunecysta spp. cf. L granosa, Selenopemphix nephroides and Cordosphaeridium inodes in establishing the Oligocene age. Zones AF4, AF5 and AF6 (P620, P630 and P650) were defined by FDO of Praedapollis africanus, increase of Praedapollis flexibillis and base quantity of Magnastriatites howardi.

Some finer scale subdivisions were, conversely, recognized in the present study. All the zones have subzones (AO1, AO2, AO3, AO4, AO5 AO6 and AO7). Subzone AO2 and AO3 were further subdivided into $\mathrm{a}$ and $\mathrm{b}$ each. These sub-zones are based on qualitative and quantitative occurrences of individual taxa and general assemblage component, subject to biological development/extermination in addition to palaeoclimatic and ecological factors.

The new palynological zonation scheme of this study uses a combination of stratigraphical tops and bases as GZ-1 well quantitative changes. The several zones and subzones were demarcated with the assistance of the recovered pollen and spores botanical and ecological affinities. Mangrove in association with fresh water swamp and rainforest vegetation pollen and spore ascribed to Polypodiaceae, Parkeriaceae, Lygodiaceae, Euphorbiaceae, Clusiaceae, Pelliceria, Caesalapinoideae, Palmae and Rhizophoraceae families are the main palynomorphs recovered in all zones resulting from assemblages of plants that are currently prevalent in the Niger Delta. The Podocarpus milanjianus pollen, charred cuticle and possibly some Poaceae pollen could have been transported by air to the locations where they were deposited from areas within the inland savannah regions.

Conclusion: Palynological studies have recognized a new detected developments in the varieties of key pollen and spore taxa. Seven main zones have been documented, AF1, AF2, AF3, AF4, AF5, AF6 and AF7 which were further subdivided into seven subzones with some having finer subdivisions with age ranged from Early Oligocene to Early Miocene. Previous undocumented occurrence trends of important indicator taxa of spores and pollen have assisted improvement of formerly used palynological zonation schemes in the Niger Delta. It is anticipated that this quantitative zonation scheme erected, will help with imminent palynostratigraphical studies in the area.

Acknowledgement: The authors are grateful to the Management of Nigerian Petroleum Development Company (NPDC) of Nigeria for donating the ditch cutting samples and providing other data used for this research work. We also appreciate Mrs. Patricia Ukere of Shell Petroleum Development Company for her useful suggestions, fruitful discussions, provision of materials and continuous follow-up during the course of this study.

\section{REFERENCES}

Adebayo, OF; Ojo, AO (2014). Miocene-Pliocene vegetation and climate dynamics of the Niger Delta basin based on palynological signatures. Journal of Environment and Earth Science 4, 5867.

Adeigbe, OC; Ochigbo, EA (2017). Biostratigraphy of Ochigbo-1 Well, Offshore Niger Delta; Evidence from Foraminiferal, Spores and Pollen. British Journal of Applied Science \& Technology. 19(5), $1-25$.

Adeonipekun, PA; Sowunmi, AM; Richards, K (2015). A new Late Miocene to Pleistocene palynomorph zonation for the western offshore Niger Delta. The Palynology, 1-15.

Akpoyovbike, AA (1978). Tertiary lithostratigraphy of Niger Delta. The American Association of Petroleum Geologists Bulletin, 62 (2), 295-306. 
Artzner, DG; Dörhöfer, G (1978). Taxonomic note: Lejeunecysta nom. Nov. pro Lejeunia Gerlach 1961 emend. Lentin and Williams 1976 dinoflagellate cyst genus. Canadian Journal of Botany, 56, 1381-1382.

Avbovbo, AA (1978). Tertiary lithostratigraphy of Niger Delta. American Association of Petroleum Geologists Bulletin. 62, 295-300.

Biffi, U; Grignani, D (1983). Peridinoid dinoflagellates cysts from the Oligocene of the Niger delta, Nigeria. 132-133.

Boboye, OA; Fowora, O (2007). Biostratigraphy of calcareous Nannofossils of well XH- 1, deep offshore, Niger Delta, Nigeria. Journal of mining and Geology, 43 (1), 175-186.

Boltenhagen, E; Salard-Cheboldaeff, M (1973). Praedapollis africanus, a new genus of Tertiary pollen from Cameroon. (Praedapollis Africanus, genre nouveau de pollen Tertiaire du Cameroun.) International Palynological Conference, $3^{\text {rd }}$, Proceedings, (Novosibirsk). Morphology and Systematics of Fossil Pollen and Spores 24-27.

Bruno, ZD; Mamery, D; Juliette Tea-Y; Raphael, KY; Jean-Paul, NY; David, KK; Ignace, T (2011). Palynostratigraphy and palaeoenvironmental characterization and evidence of Oligocene in the terrestrial sedimentary basin, Bingerville area, Southern Côte d'Ivoire, Northern Gulf of Guinea. African Journal of Environmental Science and Technology 6 (1), 28-42.

Clarke, RT (1966). Peregrinipollis nigericus, a new palynomorph from the Upper Tertiary of Nigeria. Grana Palynol. 6 (3), 544-546.

Doust, H; Omatsola, E (1990). Niger Delta. In: Edwards, J.D., and Santogrossi, P.A., eds., Devergent/passive Margin Basins, AAPG Memoir 48: Tulsa, American Association of Petroleum Geologists, 201-238.

Durugbo, EU (2013). Palynostratigraphy, age determination and depositional environments of Imo Shale Exposures at the Okigwe/Port Harcourt Express Road Junction Okigwe, Southeastern Nigeria. Greener Journal of Physical Science 3, 255-272.

Ekweozor, CM; Okoye, NV (1980). Petroleum sourcebed evaluation of Tertiary Niger Delta: American
Association of Petroleum Geologists Bulletin, 64, 1251-1259.

Essien, AE; Beka, FT; Mkpong, EO (2016). Palaeofloristic Variations across Oligocene / Miocene Boundary in Niger Delta, Nigeria. Journal of Scientific and Engineering Research, 3(3), 624-638.

Evamy, BD; Haremboure, J; Kamerling, P; Knaap, WA; Molloy, FA; Rowlands, PB (1978). Hydrocarbon habitat of Tertiary Niger Delta. American Association of Petroleum Geologists Bulletin. 62, 1-39.

Germeraad, JH; Hopping, CA; Muller, J (1968). Palynology of Tertiary sediments from tropical areas: Review of Paloebotany and Palynology, 6, 189-348.

Jardine, S; Magloire, L (1965). Palynologie et starigraphie de Cretace des Bassins du Senegal et de Cote d'Ivoire: Mem. - Premier Colloq. Afric. Micropaléont. Dakar, 1963; Mém. Bur. Rech. Géol. Min., 32, 187-245.

Kar, RK (1992). Occurrence of Acrosticum spores from the Langpar Formation Early Palaeocene of Meghala, India. Geophytology, 22, 33-36.

Lambert-Aikhionbare, DO; Ibe AC (1984). Petroleum source-bed evaluation of the Tertiary Niger Delta: discussion: American Association of Petroleum Geologists Bulletin, 68, 387-394

Lawrence, SR; Munday, S; Bray, R (2002). Regional geology and geophysics of the eastern Gulf of Guinea (Niger Delta to Rio Muni): The Leading Edge, 21 (11), 1112-1117.

Legoux, O (1978). Quelques especes de pollen caracteristiques du Neogene du Nigeria: Bull. Cent. Rech. Explor. - Prod. Elf-Aquitane, 2 (2), 265-317.

Morley, RJ (2000). Origin and evolution of Tropical Rain Forests. UK: Wiley. 362.

Morley, RJ (1996a). Biostratigraphic characterization of systems tracts in Tertiary sedimentary basins. Proceedings of the International Symposium on Sequence Stratigraphy in SE Asia; 1996; Jakarta. Indonesia Petroleum

Morley, RJ (1996b). Biostratigraphic characterization of systems tracts in the offshore Niger Delta. 14th 
Annual Conference Nigerian Association of Petroleum Explorationists; November 1996; Lagos. (Abstract only).

Oboh-Ikuenobe, FE; Yepes, O (1997). Palynofacies analysis of sediments from the Côte d'Ivoire Ghana transform margin: preliminary correlation with some regional events in the Equatorial Atlantic. Palaeogeogr, Palaeoclimatol, Palaeoecol. 129, 291-314.

Oloto, IN (2014). Biostratigraphic Study and Paleoenvironmental Reconstruction of Cores from Offshore (South Western) Niger Delta, Nigeria. International Journal of Scientific \& Technology

Research 3, 279-286.

Potonie, R; Gelletich, I (1933). Uber Pteridophyten sporen einer Eozanen braunkohle aue Dorog in Ungarn. Sitzungsberichte der Gasellschaft NaturforschenderFreunde, 33, 517-528.

Poumot, C (1989). Palynological evidence for eustatic events in the tropical Neogene. Bull. Cent. Rech. Explor. Prod. Elf-Aquitaine 13, 437-452.

Reijers, TJA; Petters, SW; Nwajide, CS (1997). The Niger Delta Basin, In: Selley RC, editor, African Basins-Sedimentary Basin of the World 3: Amsterdam, Elsevier Science, 151-172.

Reijers, TJA (2011). Stratigraphy and sedimentology of the Niger Delta. Geologos, 17, 133-162.

Salard-Cheboldaeff, M (1990). Intertropical African palynostratigraphy from Cretaceous to Late Quaternary times. Journal of African Earth Sciences, 11, 1-24.

Sah, SCD (1967). Palynology of an Upper Neogene profile from Rusizi Valley (Burundi). Koninklijk Museum voor Midden-Afrika - Tervuren, Belgie Annalen - Reeks in $-8^{\circ}$ - Geologische Wetenschappen, 57, 173.
Short, KC; Stauble, AJ (1967). Outline of geology of Niger Delta: American Association of Petroleum Geologists Bulletin, 51, 761 - 779.

Thomson, PW; Pflug, H (1953). Pollen und Sporen des mitteleuropaischen Tertiars. - Paliiontographica, B, 94, 1-4, 1-138

Van Der Hammen, T (1956b). Description of some genera and species of fossil pollen and spores-Bol. Geol. (Bogotá), 4, 111-117.

Van Der Hammen, T; Wymstra, TA (1964). A palynological study on the Tertiary and Upper Cretaceous of British Guiana. - Leidse Geol. Mededel., 30, 183-241.

Weber, KJ (1971). Sedimentological aspects of oilfields in the Niger Delta. Geologie en Mijnbouw. 50, 559-576.

Weber, KJ; Daukoru, EM (1975). Petroleum geology of the Niger delta: Proceedings of the 9th World Petroleum Congress, Tokyo, 2, 202-221.

William Gosling, D; Charlotte, MS; Livingstone, DA (2013). Atlas of the tropical West African pollen flora. Review of Palaeobotany and Palynology (In press).

Wood, GD; Gabriel, AM; Lawson, JC (1996). Palynological techniques - processing and microscopy, in J. Jansonius and D.C. MaGregor, eds., Palynology: Principles and Applications: American Association of Stratigraphy Palynologists Foundations, 1, 29 -50. 